\title{
Short-term iodine dynamics in soil solution
}

Olivier S. Humphrey ${ }^{\dagger \ddagger}$, Scott D. Young ${ }^{\ddagger}$, Neil M. J. Crout ${ }^{\ddagger}$, Elizabeth H. Bailey ${ }^{\ddagger}$, E. Louise Ander ${ }^{\dagger}$, and Michael J. Watts ${ }^{\dagger *}$

${ }^{\dagger}$ Inorganic Geochemistry, Centre for Environmental Geochemistry, British Geological Survey, Keyworth, Nottingham NG12 5GG, UK.

$\$$ School of Biosciences, University of Nottingham, Sutton Bonington Campus, Leicestershire, LE12 5RD, UK

\section{ABSTRACT}

Assessing the reactions of iodine (I) in soil is critical to evaluating radioiodine exposure and understanding soil-to-crop transfer rates. Our mechanistic understanding has been constrained by method limitations in assessing the dynamic interactions of iodine between soil solution and soil solid phase over short periods (hours). We use microdialysis to passively extract soil solution spiked with radioiodine $\left({ }^{129} \mathrm{I}^{-}\right.$and $\left.{ }^{129} \mathrm{IO}_{3}{ }^{-}\right)$, to monitor short-term ( $\leq 40$ hours) in-situ fixation and speciation changes. We observed greater instantaneous adsorption of ${ }^{129} \mathrm{IO}_{3}{ }^{-}$compared to ${ }^{129} \mathrm{I}^{-}$in all soils and the complete reduction of ${ }^{129} \mathrm{IO}_{3}{ }^{-}$to ${ }^{129} \mathrm{I}^{-}$within 5 hours of addition. Loss of ${ }^{129} \mathrm{I}$ from solution was extremely rapid; the average half-life of ${ }^{129} \mathrm{I}^{-}$and ${ }^{129} \mathrm{IO}_{3}{ }^{-}$in soil solution was 4.06 and 10.03 hours, respectively. We detected the presence of soluble organically bound iodine (org- ${ }^{129} \mathrm{I}$ ) with a low molecular weight (MW) range $(0.5-5 \mathrm{kDa})$ in all soils and a slower (20 to 40 hours) time-dependent formation of larger MW org-I compounds (12-18 kDa) in some samples. This 
doi: 10.1021/acs.est.9b02296

study highlights the very short window of immediate availability in which I from rainfall or irrigation remains in soil solution and available to crops, thus presenting significant challenges to phytofortification strategies in soil-based production systems.

\section{Introduction}

Iodine (I) is an essential micronutrient for mammalian life, required for the synthesis of thyroid hormones, approximately 1.9 billion people worldwide are estimated to be at risk of developing an iodine deficiency disorder. ${ }^{1,2}$ Radioiodine $\left({ }^{129} \mathrm{I} ; \mathrm{t}_{1 / 2}=1.57 \times 10^{7} \mathrm{yr}\right.$ and $\left.{ }^{131} \mathrm{I} ; \mathrm{t}_{12} 8.02 \mathrm{~d}\right)$ released as a consequence of anthropogenic activities poses a major ecological and health concern due to its biophilic properties and relatively high environmental mobility. ${ }^{3}$ Once ${ }^{129} \mathrm{I}$ enters the environment, it behaves similarly to ${ }^{127} \mathrm{I}$, capable of bioaccumulating through the food chain and subsequently stored in the thyroid where it can induce tumors. ${ }^{4-6}$ Understanding the biogeochemical processes and mechanisms that affect I cycling in the terrestrial environment is critical to evaluating the cause of I deficiency and potentially harmful exposure to radioiodine isotopes.

Soil properties including $\mathrm{pH}$, redox potential, concentration of soil organic matter (SOM) and $\mathrm{Fe} / \mathrm{Al} / \mathrm{Mn}$ hydrous oxides affect I fixation, mobility and speciation. ${ }^{5,-11}$ Following natural and anthropogenic I addition events (e.g. rainfall, irrigation, nuclear weapons testing), soluble inorganic-I species, iodide $\left(\mathrm{I}^{-}\right)$and iodate $\left(\mathrm{IO}_{3}{ }^{-}\right)$, can be converted to soluble organic compounds (org-I) and/or incorporated into the solid soil phase, bound to SOM or adsorbed to metal oxides. . $^{5-}$ 7,9, 12 It was demonstrated previously that $\mathrm{IO}_{3}{ }^{-}$and org-I are less mobile and have a greater affinity for solid-soil components compared to $\mathrm{I}^{-} \cdot{ }^{12-14}$ Metal hydrous oxides can influence iodine dynamics in soils. Whilst ferric and aluminum oxides adsorb $\mathrm{IO}_{3}{ }^{-}$more strongly than $\mathrm{I}^{-},{ }^{13}$ the presence of 
doi: 10.1021/acs.est.9b02296

manganese oxide birnessite $\left(\delta-\mathrm{MnO}_{2}\right)$ can oxidize $\mathrm{I}^{-}$to $\mathrm{IO}_{3}{ }^{-} \cdot{ }^{15}$ However, in the presence of organic matter $(\mathrm{OM})$ the oxidation of $\mathrm{I}^{-}$to $\mathrm{IO}_{3}{ }^{-}$is limited as the intermediate product, $\mathrm{I}_{2}$, is incorporated into $\mathrm{OM}(\mathrm{pH}<7) .{ }^{16}$ Whilst the $\mathrm{pH}$ and redox potential of soils affects I speciation and mobility, SOM appears to be the dominant factor controlling I retention in soils. ${ }^{12,17,18}$

Microdialysis is an established method for neuroscience and pharmacokinetics and has been used to investigate the mobility and bioavailability of macro-nutrients and metal ions in soil ${ }^{19-22}$; its applicability for following I reaction dynamics was previously evaluated by the authors. ${ }^{23}$ The passive sampling conditions of microdialysis enable the extraction of the soil solution phase with high temporal resolution and minimal disturbance to the soil structure. Unlike conventional soil solution sampling methods which are destructive (e.g. centrifugation, high-pressure squeezing) or require soil to be close to saturation (e.g. Rhizon ${ }^{\mathrm{TM}}$ samplers), microdialysis can perform continuous extractions of the soil solution at a wide range of water contents (as low as $\sim 50 \%$ water holding capacity (WHC)). Evaluating soluble I without disturbing the ambient soil conditions, which could result in changes in I speciation, is vital for a more detailed understanding of I biogeochemistry in soil.

In this study, we investigated short-term soil soluble I dynamics in three soils with contrasting physicochemical properties. Microdialysis was used to sample an isotopic I tracer $\left({ }^{129} \mathrm{I}\right)$ under ambient soil conditions to monitor changes in concentration and speciation following an addition event at 2.5 hour (hr) intervals over a $40 \mathrm{hr}$ period. Iodine in the sampled dialysate was analyzed and speciated to determine: (i) the rate at which inorganic-I is removed from soil solution and adsorbed to the soil solid phase; and, (ii) the molecular weight (MW) range of soluble org-I compounds which are formed. 
doi: 10.1021/acs.est.9b02296

\section{Materials and Methods}

\section{Soil sampling and physiochemical characteristics}

Three topsoils $(0-10 \mathrm{~cm})$, from adjoining arable, grassland and woodland sites, were collected from a location in Nottinghamshire, UK. The soils were sieved to $<2 \mathrm{~mm}$, homogenized and airdried. Soil $\mathrm{pH}$ was determined using an Orion $\mathrm{pH}$ meter after equilibrating $5 \mathrm{~g}$ of soil in $12.5 \mathrm{~mL}$ of $0.01 \mathrm{M} \mathrm{CaCl}_{2}$ for $30 \mathrm{~min}$. Loss-on-ignition (LOI), as an estimate of SOM content, was determined after heating in a muffle furnace at $450{ }^{\circ} \mathrm{C}$ for $16 \mathrm{hr}$, after an initial drying period. The water holding capacity (WHC) of the soil was determined gravimetrically in triplicate according to Grace, et al. ${ }^{24}$. Total soil ${ }^{127}$ I was extracted with $5 \%$ tetramethylammonium hydroxide (TMAH) at $70{ }^{\circ} \mathrm{C}$ for $3 \mathrm{hr}$ (with shaking after $1.5 \mathrm{hr}$ ); once cooled, $5 \mathrm{~mL}$ of Milli-Q water was added and the bottles were centrifuged ( $20 \mathrm{~min}$ at $3500 \mathrm{rpm}$ ) and the supernatant solutions retained for analysis by ICP-QQQ. ${ }^{25}$ To determine the concentrations of reactive iron, aluminum, and manganese hydrous oxides, soils were extracted with dithionite-citrate-bicarbonate (DCB) solution, centrifuged $(20 \mathrm{~min}$ at $2500 \mathrm{rpm})$, filtered $(<0.22 \mu \mathrm{m})$ and the supernatant solutions retained for analysis by ICP-QQQ. ${ }^{26}$ Particle size analysis was determined using the method described in Rawlins, et al. ${ }^{27}$, using a laser diffraction particle size analyzer.

\section{Soil incubation and microdialysis sampling}

The radioiodine tracer $\left({ }^{129} \mathrm{I}\right)$ was obtained from the American National Institute of Standards as NaI (NIST, Gaithersburg, Maryland, USA; CRM 4949C, $0.004 \mathrm{~mol} \mathrm{~L}^{-1} \mathrm{Na}^{129} \mathrm{I}, 3451 \mathrm{~Bq} \mathrm{~mL}^{-1}$ ). The primary stock $\left({ }^{129} \mathrm{I}^{-}\right)$was made up to $100 \mathrm{~mL}$ with $0.01 \mathrm{M} \mathrm{NaOH}$, as recommended by the suppliers. Iodate $\left({ }^{129} \mathrm{IO}_{3}{ }^{-}\right)$was prepared from the ${ }^{129} \mathrm{I}^{-}$stock by oxidation, using a method adapted from Yntema and Fleming ${ }^{28}$. To $50 \mathrm{~mL}$ of the ${ }^{129} \mathrm{I}^{-}$stock, $5 \mathrm{~mL}$ of $0.1 \mathrm{M} \mathrm{HCl}$ was added in an 
doi: 10.1021/acs.est.9b02296

initial neutralization step, followed immediately by $5 \mathrm{~mL}$ of $0.2 \mathrm{M}$ sodium chlorite for oxidation. Successful oxidation to ${ }^{129} \mathrm{IO}_{3}{ }^{-}$was confirmed by anion exchange LC-ICP-QQQ. The water content of the air-dried soils ( $\sim 90 \mathrm{~g}$ dry weight $(\mathrm{dw})$ ) was raised to $50 \%$ of WHC with Milli-Q water (18.2 $\mathrm{M} \Omega \mathrm{cm}$; Millipore) and allowed to equilibrate for 10 days at $20 \pm 0.5^{\circ} \mathrm{C}$ in the dark. The moist soils were then homogenized with equivalent volumes of ${ }^{129} \mathrm{I}^{-}$or ${ }^{129} \mathrm{IO}_{3}{ }^{-}$in solution to bring the soils to $80 \%$ WHC with a final ${ }^{129}$ I concentration of $0.2 \mathrm{mg} \mathrm{kg}^{-1}$ (dw basis). The soils were then distributed between triplicate $50 \mathrm{~mL}$ Corning ${ }^{\circledR}$ polypropylene centrifuge tubes $(\sim 30 \mathrm{~g}$ $\mathrm{dw}$ of soil per replicate).

The microdialysis system consisted of a syringe pump (KD Scientific Legato 200 Series), equipped with four plastic syringes (BD Plastipak; $20 \mathrm{~mL}$ ) used to deliver the perfusate solution. Syringes were attached to microdialysis probes CMA 20 (10 mm length, $500 \mu \mathrm{m}$ outer and 400 $\mu \mathrm{m}$ inner diameter) with a polyethersulfone (PES) membrane (100 kDa molecular weight cut-off (MWCO). Within two minutes of ${ }^{129}$ I addition to soil, incision holes were made, using an introducing needle, and the microdialysis probes were inserted $\sim 1.5 \mathrm{~cm}$ beneath the soil surface. Probes were perfused with Milli-Q water at a flow rate of $5 \mu \mathrm{L} \mathrm{min}{ }^{-1}$ and dialysate solutions collected at $2.5 \mathrm{hr}$ intervals in glass microvials over a $40 \mathrm{hr}$ extraction period. Samples were initially stored in the refrigerated micro-fraction collector $\left(6^{\circ} \mathrm{C}\right.$; CMA 470$)$ before freezing at -20 ${ }^{\circ} \mathrm{C}$ until defrosting immediately before analysis. Throughout the extraction, soils were kept in the dark at a constant temperature of $20 \pm 0.5^{\circ} \mathrm{C}$. The probes and micro-fraction collector were from CMA Microdialysis AB (Kista, Sweden). In order to assess the concentration $\left(\mu \mathrm{g} \mathrm{L}^{-1}\right)$ of ${ }^{129} \mathrm{I}$ in the soil solution a correction factor was applied to the measured dialysate solutions as $\mathrm{C}_{\text {soil_solution }}$ $=\mathrm{C}_{\text {dialysate }} /\left(1-\mathrm{e}^{-P S / F}\right)$. Where $\mathrm{C}_{\text {soil_solution }}$ and $\mathrm{C}_{\text {dialysate }}$ are the concentrations of the target analyte in 
doi: 10.1021/acs.est.9b02296

the external soil solution and the dialysate solution respectively, PS in the surface area of the microdialysis membrane and $F$ is the perfusion flow rate, adapted from Clough ${ }^{29}$.

\section{Total iodine analysis}

Total ${ }^{127}$ I concentrations were determined in single MS, no-gas mode (Agilent 8900 ICP-QQQ, Agilent Technologies). All ${ }^{129}$ I concentrations were measured using an ICP-QQQ (Agilent 8900, Agilent Technologies). Analysis was conducted using both quadrupoles and the reaction cell, to remove isobaric and polyatomic interferences, a full description of ${ }^{129} \mathrm{I}$ analysis can be found in Humphrey, et al. ${ }^{30}$. Due to the small sample volume, we used an Agilent 1260 Infinity Bio-inert Quaternary LC pump and high performance autosampler to act as a low volume autosampler: vials were also equipped with flat bottomed glass inserts to further reduce the sample volume requirement. Throughout the analytical run, an in-house quality control sample with a known concentration of $5 \mu \mathrm{g} \mathrm{L}^{-1} 129$ I was measured with an average recovery of $101 \%(n=28)$ and a limit of detection (LOD) (3 x SD blanks) of $0.0075 \mu \mathrm{g} \mathrm{L}{ }^{-1}$ for ${ }^{129} \mathrm{I}$.

\section{Iodine speciation analysis}

Inorganic-I $\left({ }^{129} \mathrm{I}^{-}\right.$and $\left.{ }^{129} \mathrm{IO}_{3}{ }^{-}\right)$concentrations were measured by ICP-QQQ following on-line chromatographic separation in isocratic mode using a Hamilton PRP X-100, anion exchange column $(250 \mathrm{~mm} \times 4.6 \mathrm{~mm}, 5 \mu \mathrm{m})$ and a samples injection volume of $25 \mu \mathrm{L}$. The mobile phase was $100 \mathrm{mM} \mathrm{NH}_{4} \mathrm{NO}_{3}$, adjusted to $\mathrm{pH} 9.5$ with TMAH (25\%), at a flow rate of $1.5 \mathrm{~mL} \mathrm{~min}{ }^{-1}$.

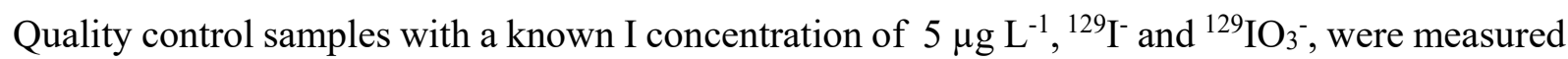
with an average recovery of $97 \%$ and $96 \%(n=22)$, respectively. The LOD for ${ }^{129} \mathrm{I}^{-}$and ${ }^{129} \mathrm{IO}_{3}{ }^{-}$ was 0.007 and $0.006 \mu \mathrm{g} \mathrm{L}^{-1}$, respectively. 
doi: 10.1021/acs.est.9b02296

The MW distribution of soluble org-I was determined using size exclusion chromatography (SEC) hyphenated with UV absorbance detection and ICP-QQQ. An Agilent 1260 Infinity Bio-inert Quaternary LC pump and high performance autosampler in isocratic mode with an AdvanceBio SEC $130 \AA$ (2.7 $\mu \mathrm{m}, 4.6$ x 300 mm column, MW range 100-120,000 Da, Agilent) was used as the sample introduction system. Samples $(10 \mu \mathrm{L})$ were injected onto the column with a mobile phase (flow rate of $0.35 \mathrm{~mL} \mathrm{~min}^{-1}$ ) consisting of $150 \mathrm{mM}$ sodium phosphate buffer, $\mathrm{pH}$ 7.0. Platinum tip sampler and skimmer cones were used on the ICP-QQQ due to the high sodium concentration in the mobile phase. The UV detector scanned at $220 \mathrm{~nm}$ to measure the calibration protein standards, and $254 \mathrm{~nm}$ to detect dissolved organic carbon. ${ }^{9,31-35}$ Protein standards of known MWs: Ovalbumin (45 kDa); Myoglobin (17 kDa); Aprotinin (6.7 kDa); Neurotensin $(1.7 \mathrm{kDa})$; and Angiotensin II $(1 \mathrm{kDa})$ (AdvanceBio SEC 130 $\AA$ protein standard, Agilent) were used to calibrate the column.

\section{Results and Discussion}

\section{Soil characteristics}

The soil physiochemical characteristics in Table 1 reflect their land use. Compared to the arable and grassland soils the acidic woodland soil had a much greater LOI, extractable $\mathrm{Fe} / \mathrm{Al} / \mathrm{Mn}$ hydrous oxide content and total I concentration. Given that all three soils were collected with 2.5 $\mathrm{km}$ of each other the greater I concentration in the woodland soil may reflect a greater ability to retain I from precipitation and the absence of annual crop removal.

Table 1 Summary of soil physiochemical characteristics. Values expressed as mean \pm standard error (SE) $(\mathrm{n}=3)$ 
doi: 10.1021/acs.est.9b02296

\begin{tabular}{|c|c|c|c|c|}
\hline & Units & Arable & Grassland & Woodland \\
\hline $\begin{array}{l}\text { Location (long, lat } \\
\text { decimal degrees) }\end{array}$ & & $52.9001,-1.0884$ & $52.8890,-1.0877$ & $52.8986,-1.0744$ \\
\hline Elevation & $\mathrm{m}$ & 95 & 83 & 121 \\
\hline $\mathrm{pH}\left(\mathrm{CaCl}_{2}\right)$ & & 6.9 & 5.9 & 3.6 \\
\hline LOI & $\%$ & 5.1 & 7.0 & 50.6 \\
\hline WHC & $\%$ & 36.8 & 41.5 & 70.8 \\
\hline${ }^{127} \mathrm{I}$ & $\mathrm{mg} \mathrm{kg}^{-1}$ & $3.38 \pm 0.05$ & $3.63 \pm 0.05$ & $12.9 \pm 0.10$ \\
\hline${ }^{129} \mathrm{I}$ & $\mu \mathrm{g} \mathrm{kg}^{-1}$ & $<\mathrm{DL}$ & $<\mathrm{DL}$ & $<\mathrm{DL}$ \\
\hline $\mathrm{Fe}_{2} \mathrm{O}_{3}$ & $\%$ & $0.180 \pm 0.02$ & $0.0131 \pm 0.001$ & $0.696 \pm 0.06$ \\
\hline $\mathrm{Al}(\mathrm{OH})_{3}$ & $\%$ & $0.0379 \pm 0.003$ & $0.0523 \pm 0.007$ & $0.925 \pm 0.05$ \\
\hline $\mathrm{MnO}_{2}$ & $\%$ & $0.0594 \pm 0.005$ & $0.0226 \pm 0.003$ & $0.622 \pm 0.07$ \\
\hline Texture (clay/silt/sand) & $\%$ mass & $41 / 41 / 18$ & $17 / 19 / 64$ & $24 / 35 / 41$ \\
\hline Texture classification & & Clay & Sandy Loam & Clay Loam \\
\hline
\end{tabular}

Total ${ }^{129}$ I dynamics in soil solution in Figure 1. 

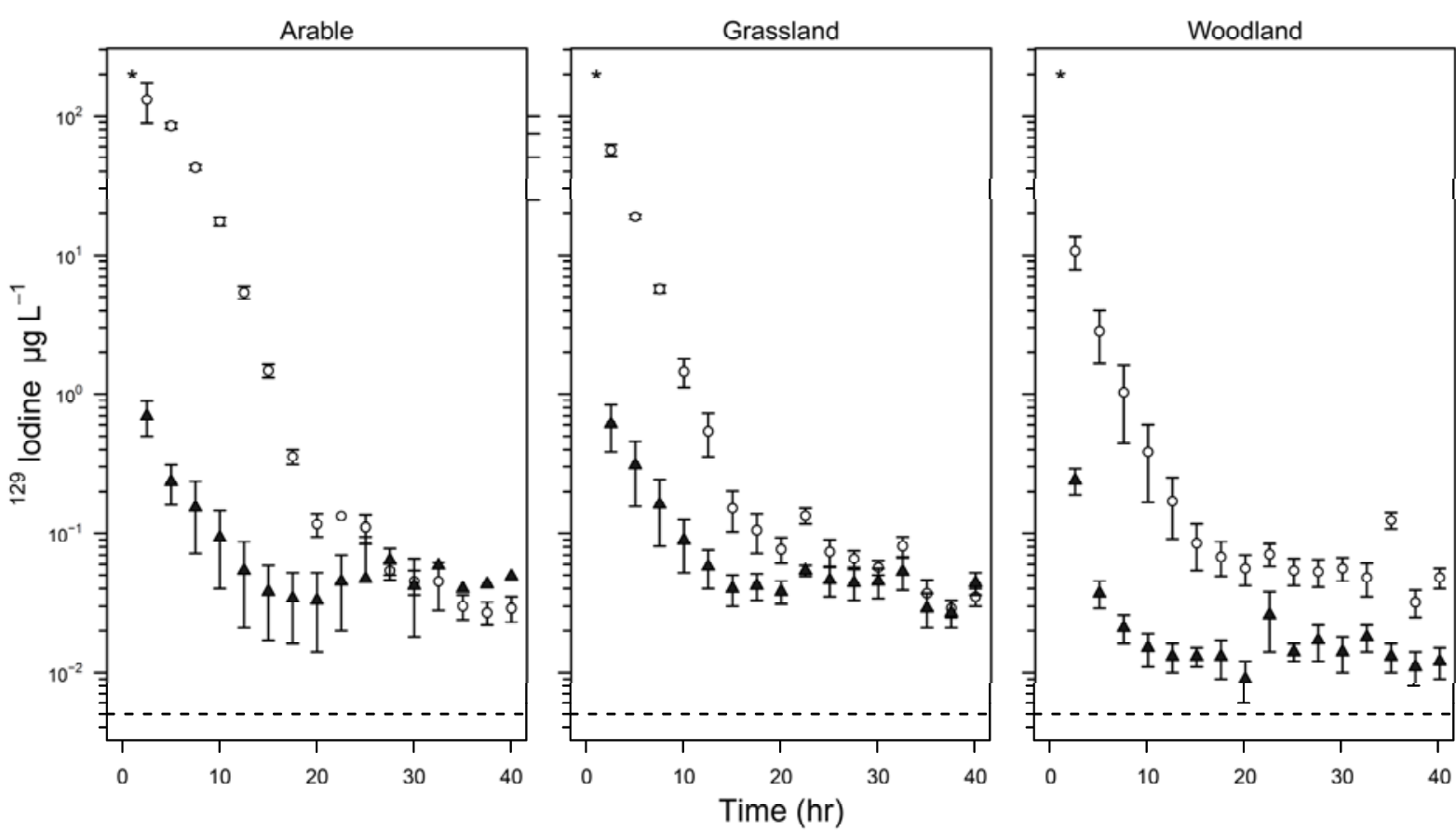

161

Figure 1 Soluble ${ }^{129} \mathrm{I}\left(\mu \mathrm{g} \mathrm{L}^{-1}\right)$ sampled using microdialysis from arable, grassland and woodland soils at 2.5 hour intervals over 40 hours. Symbols represent mean values obtained in triplicate, error bars indicate \pm S.E. An asterisk at the top left of each chart denotes the initial spike concentration; white circles $(\circ)$ represent soils spiked with ${ }^{129} \mathrm{I}^{-}$; black triangles $(\boldsymbol{\Delta})$ represent soils spiked with ${ }^{129} \mathrm{IO}_{3}{ }^{-}$. Note the log scale on the Y-axis. The dashed line indicates the detection limit. Each microdialysis dialysate sample was sampled at $5 \mu \mathrm{L} \mathrm{min}{ }^{-1}$ for 2.5 hours.

Losses of ${ }^{129} \mathrm{I}$ from soil solution were observed in all the soils within $2.5 \mathrm{hr}$, irrespective of the initial spike speciation $\left({ }^{129} \mathrm{I}^{-}\right.$or $\left.{ }^{129} \mathrm{IO}_{3}{ }^{-}\right)$. The concentration of ${ }^{129} \mathrm{I}$ in the first dialysate samples $(0-$ $2.5 \mathrm{hr}$ ) were significantly higher in soils treated with ${ }^{129} \mathrm{I}^{-}$compared to ${ }^{129} \mathrm{IO}_{3}{ }^{-}$. The significantly larger initial loss of ${ }^{129} \mathrm{IO}_{3}{ }^{-}$from solution compared to ${ }^{129} \mathrm{I}^{-}$observed in this study may be a combination of adsorption on inorganic soil phases or, rapid immobilization within $\mathrm{SOM}^{5}$ 
doi: 10.1021/acs.est.9b02296

Volatilization has previously been reported to occur from soils, but is suppressed by the presence of $\mathrm{SOM}^{6}$ and the likelihood of it meaningfully contributing to total loss rates is low. ${ }^{36}$ Therefore, adsorption onto inorganic soil phases and rapid immobilization by SOM are far more likely reasons for the losses of ${ }^{129}$ I from soil solution; both of these processes are $\mathrm{pH}$-dependent. Prior to the incorporation of $\mathrm{IO}_{3}{ }^{-}$with $\mathrm{OM}$ studies have shown that a reduction to an electrophilic intermediate species, such as $\mathrm{HOI}$ or $\mathrm{I}_{2}$ occurs, this reduction occurs much faster under acidic conditions $(\mathrm{pH}<$ 6). ${ }^{16,37-40}$ Clays, hydrous oxides and SOM can absorb $\mathrm{I}^{-}$, where sorption generally increases with decreasing $\mathrm{pH}$, as observed in this study. ${ }^{41-43}$ In previous studies it has been shown that when soil $\mathrm{pH}>6.0 \mathrm{I}^{-}$sorption is predominantly influenced by $\mathrm{OM}$, however, under more acidic conditions the role of specific adsorption to iron and aluminum oxides becomes increasingly important. ${ }^{44,45}$ The faster immediate sorption of ${ }^{129} \mathrm{IO}_{3}{ }^{-}$compared to ${ }^{129} \mathrm{I}^{-}$highlights the different adsorption mechanisms of inorganic-I in soils.

The significant proportion of apparent instantaneous loss of ${ }^{129} \mathrm{IO}_{3}^{-}$from solution in all experimental soil and the highest loss rates of ${ }^{129} \mathrm{I}^{-}$from soil solution is consistent with previous results. ${ }^{5}$ First-order kinetic equations were used to assess the rate at which total ${ }^{129}$ I was removed from soil solution as: $\mathrm{C}_{\mathrm{t}}=\mathrm{C}_{\mathrm{o}} \mathrm{e}^{-k t}$, where $\mathrm{C}_{\mathrm{t}}$ is the ${ }^{129} \mathrm{I}$ concentration at time $\mathrm{t}(\mathrm{hr})\left(\mathrm{mg} \mathrm{L}^{-1}\right), \mathrm{C}_{\mathrm{o}}$ is the initial concentration of ${ }^{129} \mathrm{I}$ in soil solution $\left(\mathrm{mg} \mathrm{L}^{-1}\right)$, and $\mathrm{k}$ is the first-order rate constant $\left(\mathrm{hr}^{-1}\right)$. The half-life in soil solution was then calculated from $\ln (2) / k$. The average half-life of soils spiked with ${ }^{129} \mathrm{I}^{-}$and ${ }^{129} \mathrm{IO}_{3}{ }^{-}$was $4.06 \pm 0.96$ and $10.03 \pm 0.78 \mathrm{hr}$, with $r^{2}$ values of 0.77 and 0.45 , respectively. Shetaya, et al. ${ }^{5}$ investigated I dynamics in soils and reported that the loss of $\mathrm{I}^{-}$from solution was extremely rapid, reaching completion over minutes-hours, whereas $\mathrm{IO}_{3}^{-}$loss from solution was slower, typically occurring over hours-days, which is consistent with the results in the present study. However, in the current study the use microdialysis has enabled far greater 
doi: 10.1021/acs.est.9b02296

sampling resolution compared to previous studies at time intervals within a similar range to the reaction times reported by Shetaya, et al. ${ }^{5}$. The results presented in this paper indicate that iodine adsorption occurs more rapidly in soils under realistic conditions than previously observed using batch sorption experiments and chemical extraction approaches.

\section{${ }^{129}$ I speciation in soil solution}

The concentrations of soluble inorganic $\left({ }^{129} \mathrm{I}^{-}+{ }^{129} \mathrm{IO}_{3}{ }^{-}\right)$and organic (total ${ }^{129} \mathrm{I}$ minus the sum of inorganic species) ${ }^{129} \mathrm{I}$ in the three soils spiked with either ${ }^{129} \mathrm{I}^{-}$or ${ }^{129} \mathrm{IO}_{3}{ }^{-}$are shown in Figure 2. A combined inorganic fraction was calculated due to the concentrations of ${ }^{129} \mathrm{IO}_{3}{ }^{-}$present in the soils treated with either ${ }^{129} \mathrm{I}^{-}$or ${ }^{129} \mathrm{IO}_{3}{ }^{-}$falling below the LOD (shown in Figure S1).
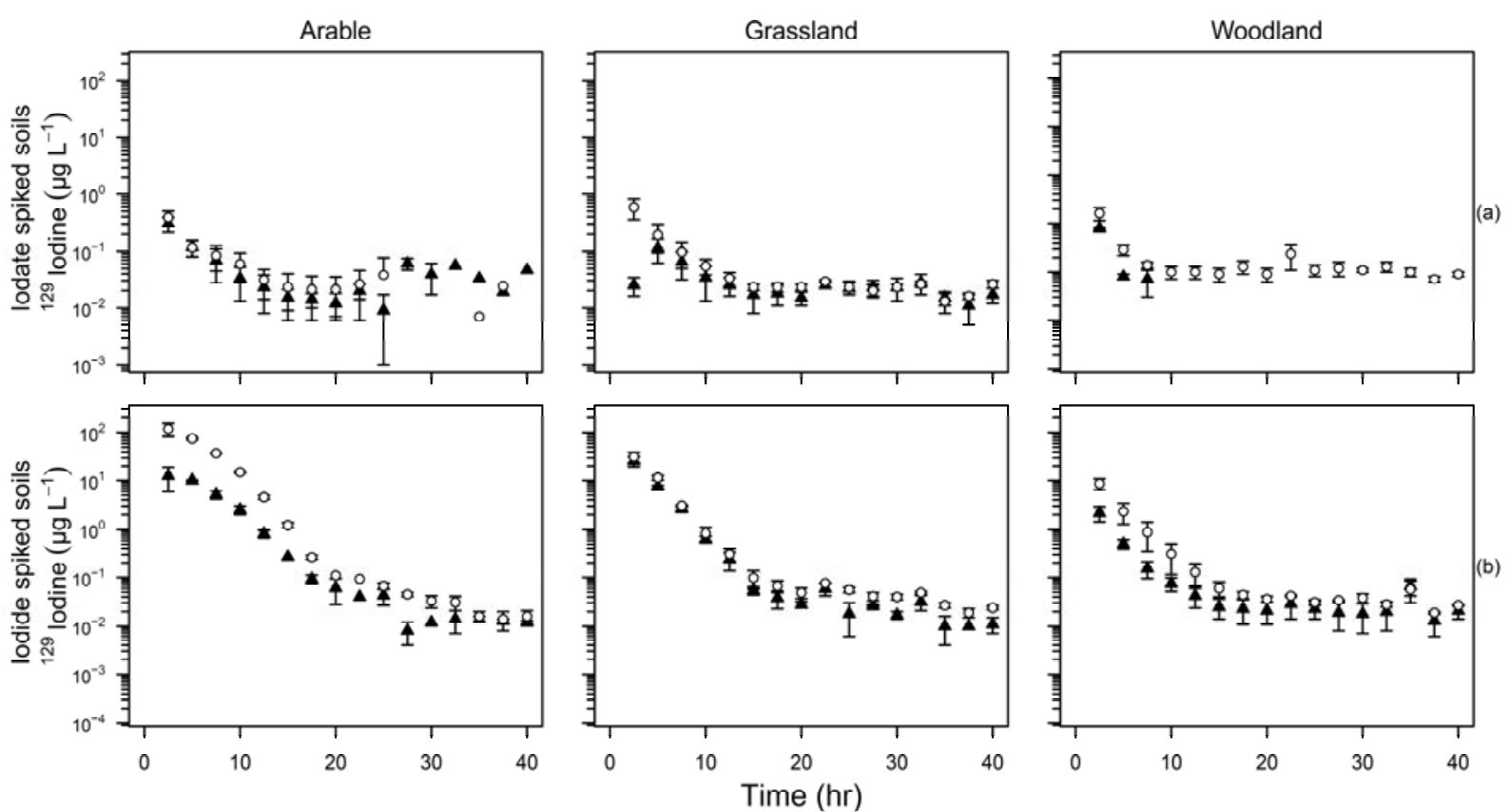

Figure 2 Soluble ${ }^{129}$ I speciation of (a) iodate and (b) iodide spiked arable, grassland and woodland soils over 40 hours. Symbols represent the mean values obtained in triplicate, bars indicate \pm SE.

White circles (०) represent inorganic- ${ }^{129}$ I concentrations; black triangles $(\boldsymbol{\Delta})$ represent soluble 
doi: 10.1021/acs.est.9b02296

org- ${ }^{129}$ I concentrations. Note the log scale on the primary Y-axis. Samples below the detection limit were omitted from the plot. Microdialysis dialysate was sampled at $5 \mu \mathrm{L} \mathrm{min}{ }^{-1}$ for 2.5 hours.

The proportion of inorganic- ${ }^{129} \mathrm{I}$ present in soil solution was greater compared to org- ${ }^{129} \mathrm{I}$ in soils spiked with $\mathrm{I}^{-}$, however, this trend was not observed consistently in $\mathrm{IO}_{3}{ }^{-}$spiked soils. In the arable soil spiked with ${ }^{129} \mathrm{IO}_{3}{ }^{-}$, where the org- ${ }^{129} \mathrm{I}$ became the dominant fraction in samples after $25 \mathrm{hr}$, when inorganic- ${ }^{129}$ I concentrations were below the LOD. In contrast, in woodland soil spiked with ${ }^{129} \mathrm{IO}_{3}{ }^{-}$the soluble org- ${ }^{129} \mathrm{I}$ fraction was below the LOD $10 \mathrm{hr}$ after addition, and only inorganic species were detected.

The speciation of stable and radioiodine present in soil systems has been the focus of several studies ${ }^{9,46-48}$ with $\mathrm{I}^{-}$and org-I identified as the dominant species present. When ${ }^{129} \mathrm{IO}_{3}{ }^{-}$was added to the soils we observed an immediate reduction to ${ }^{129} \mathrm{I}^{-}$in soil solution, with very low concentrations of ${ }^{129} \mathrm{IO}_{3}{ }^{-}$remaining in soil solution beyond 2.5 hrs (Figure S1, d). Reduction of $\mathrm{IO}_{3}{ }^{-}$to $\mathrm{I}^{-}$in soils has previously been observed ${ }^{49,50}$ and may arise from biotic processes. However, it seems more likely that reduction is caused by abiotic interactions with solid or dissolved OM as the reaction rates appear to be too rapid for biological processes. ${ }^{5}$ The rapid reduction reported in this study is much faster compared to previous work, where the reduction of $\mathrm{IO}_{3}{ }^{-}$occurred over days. ${ }^{51}$ Possible reasons for the discrepancies between the studies include the significantly lower concentrations of ${ }^{129} \mathrm{I}$ used in this study and the lower soil $\mathrm{pH}$ used in this study as the reduction of $\mathrm{IO}_{3}{ }^{-}$to the reactive iodine species is thermodynamically more favorable at lower $\mathrm{pH}$.

In contrast, when soils were spiked with ${ }^{129} \mathrm{I}^{-}$, a very low concentration of ${ }^{129} \mathrm{IO}_{3}{ }^{-}$was detected in the arable and grassland soils within $7.5 \mathrm{hr}$, indicating that limited ${ }^{129} \mathrm{I}^{-}$oxidation to ${ }^{129} \mathrm{IO}_{3}{ }^{-}$had occurred (Figure S1). We only observed $\mathrm{I}^{-}$oxidation in the arable and grassland soils; there was 
doi: 10.1021/acs.est.9b02296

no evidence for oxidation in the organic-rich acidic woodland soil (Figure S1). Factors controlling ${ }^{129} \mathrm{I}^{-}$oxidation in soil remain unclear. ${ }^{52}$ The conversion of $\mathrm{I}^{-}$to org-I requires $\mathrm{I}^{-}$to be initially oxidized to an intermediate such as $\mathrm{I}_{2}$ or HOI. ${ }^{16,37}$ Iodide-oxidizing bacteria in soils have previously been observed to influence $\mathrm{I}^{-}$sorption/incorporation into SOM and oxidation to $\mathrm{IO}_{3}{ }^{-}$ and to produce volatile org-I compounds such as $\mathrm{CH}_{3} \mathrm{I}^{53,}{ }^{54} \mathrm{In}$ addition, metal oxides (Al, $\mathrm{Fe}, \mathrm{Mn}$ ) and humic substances can act as oxidizing agents. In batch kinetic experiments $\mathrm{pH}$ and metal oxide concentrations significantly influence reaction rates, with faster oxidation occurring at lower $\mathrm{pH}$ and greater metal oxide concentrations. ${ }^{55,56}$ However, in our in-situ experiments, we did not observe $\mathrm{I}^{-}$oxidation in the acidic, $\mathrm{Fe} / \mathrm{Al} / \mathrm{Mn}$ rich woodland soil. Figure 2 shows that the greatest initial loss of $\mathrm{I}^{-}$occurred in the woodland soil, which had the largest metal oxide concentrations, an order of magnitude higher than the arable and grassland soils, highest organic matter and the lowest $\mathrm{pH}$. The rapid loss of $\mathrm{I}^{-}$from solution in organic-rich soils has been described as a firstorder reaction. ${ }^{57}$ Previous studies have demonstrated that $\mathrm{I}^{-}$can easily be remobilized as it is only bound by weak electrostatic attraction to solid soil media, ${ }^{57}$ therefore, further studies assessing the speciation of iodine during dynamic processes such as rainfall events or plant uptake should be investigated to assess iodine mobility in soils.

\section{Molecular weight distribution of dissolved organic ${ }^{129} I$}

The presence of org- ${ }^{129}$ I was confirmed using SEC-ICP-QQQ; the presence of multiple peaks indicates that soluble org-I exists at a range of MWs. Time-dependent changes in speciation and molecular weight of ${ }^{129} \mathrm{I}$ in the soil solution phase are shown in Figure 3. 

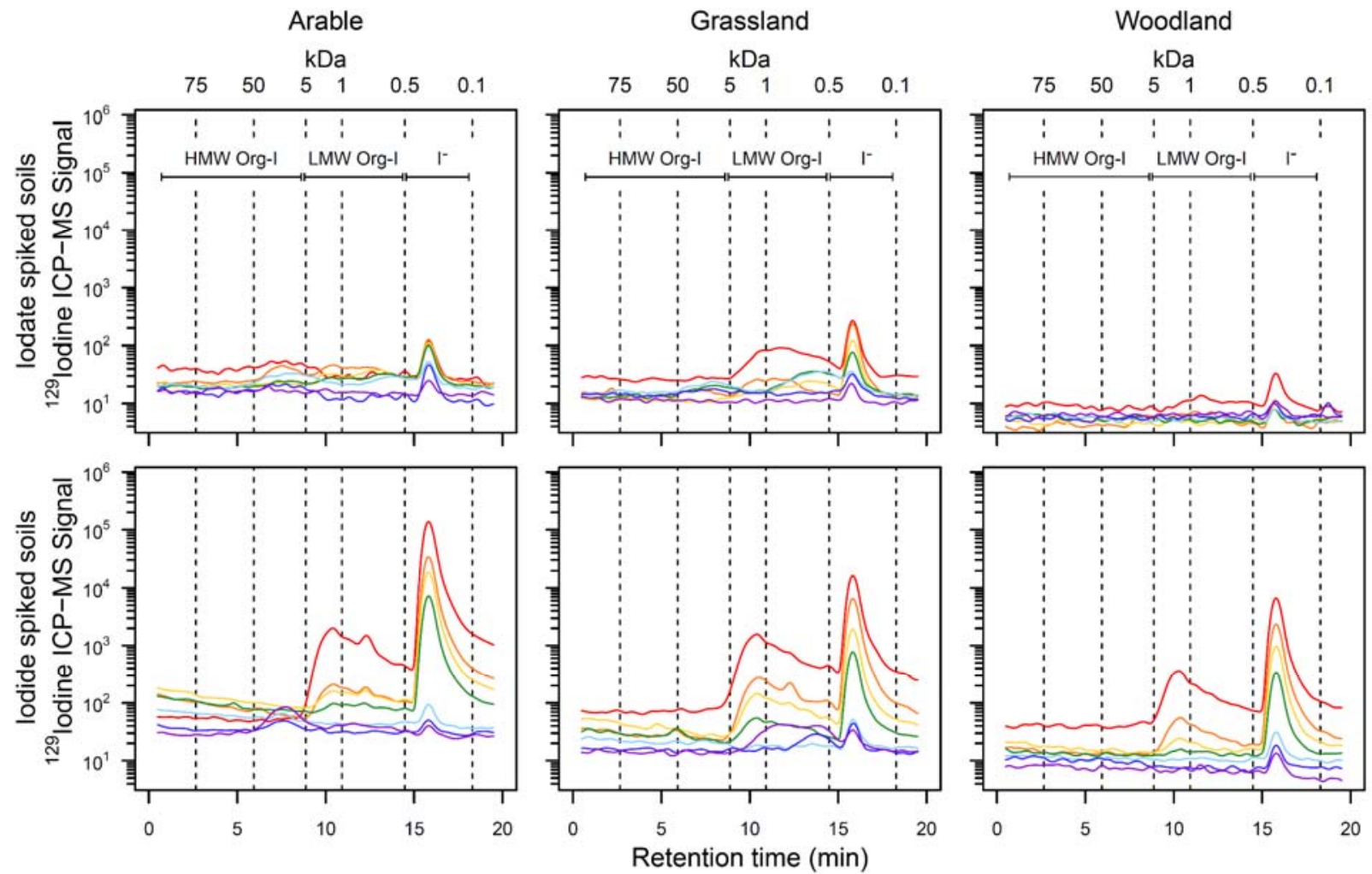

Figure 3 Molecular weight distribution of soluble isotopically labeled ${ }^{129} \mathrm{I}$ in arable, grassland and woodland soils spiked with ${ }^{129} \mathrm{IO}_{3}{ }^{-}$or ${ }^{129} \mathrm{I}^{-}$sampled over 40 hours, separated by size exclusion chromatography. Note the log Y-axis. High molecular weight organically bound I (HMW org-I), low molecular weight organically bound I (LMW org-I) and ${ }^{129} \mathrm{I}^{-}$retention times labeled.

Within all three experimental soils, for addition of both ${ }^{129} \mathrm{I}^{-}$and ${ }^{129} \mathrm{IO}_{3}{ }^{-}$, chromatographic peaks were observed for ${ }^{129} \mathrm{I}^{-}$between 15 and $18 \mathrm{~min}$ that decreased over the $40 \mathrm{hr}$ extraction period. The intensity of the ${ }^{129} \mathrm{I}^{-}$peak was considerably less in the ${ }^{129} \mathrm{IO}_{3}{ }^{-}$treated soils due to the higher rates of instantaneous adsorption on inorganic soil phases and rapid immobilization by SOM. All soils spiked with ${ }^{129} \mathrm{I}^{-}$, had a broad peak representing LMW org- ${ }^{129} \mathrm{I}$ between 9 and $15 \mathrm{~min}$; the overall intensity of the org-I peak decreased over the $40 \mathrm{hr}$ sampling period. There was a shift in the MW distribution in the arable soil spiked with ${ }^{129} \mathrm{I}^{-}$between 20 and $40 \mathrm{hr}$ when the signal intensity of 
doi: 10.1021/acs.est.9b02296

the LMW org-I peak decreased and a HMW org-I peak, with a retention time between 5 and 10 min emerged. In contrast, within the grassland soil spiked with ${ }^{129} \mathrm{I}^{-}$, dissolved org- ${ }^{129} \mathrm{I}$ had a lower MW distribution; no org-I compounds $>5 \mathrm{kDa}$ were present throughout the sampling period. The emergence and rapid decline of LMW org- ${ }^{129} \mathrm{I}$ between $0.5-5 \mathrm{kDa}$ in the woodland soil further illustrates how quickly initially soluble I is removed from solution in organic rich soils. However, within the arable and grassland soils, the MW distribution of the org-I underwent various changes within the $40 \mathrm{hr}$ sampling period. The UV absorbance results confirmed that soluble organic compounds had a broad MW range (Figure S2).

The transport behavior of inorganic-I in soils may be significantly impacted by the fixation of dissolved I into macromolecular humic substances, however, many of the mechanisms controlling the rate of fixation remain unknown. ${ }^{33,38,58,59} \mathrm{Xu}$, et al. ${ }^{3}$ demonstrated that higher proportions of ${ }^{125} \mathrm{I}^{-}$and ${ }^{125} \mathrm{IO}_{3}{ }^{-}$were associated with organic compounds $<3 \mathrm{kDa}, 16$ and $20 \%$ compared to 6 and $3 \%$ in the $>3 \mathrm{kDa}$ fraction, respectively. In addition, they found that binding sites became saturated and less available when the treatment concentration increased. ${ }^{3}$ In resuspension experiments, $\mathrm{Xu}$, et al. ${ }^{18}$ found that mobile ${ }^{129}$ I was associated with amphiphilic organic compounds with an average MW between 13.5 and $15 \mathrm{kDa}$. Figure 3 shows that higher proportions of soluble inorganic-I were incorporated into organic compounds with a low MW $(<5 \mathrm{kDa})$. However, there was evidence of larger dissolved org-I compounds with a MW between 12 and $18 \mathrm{kDa} 20 \mathrm{hr}$ after ${ }^{129} \mathrm{I}$ addition, in agreement with $\mathrm{Xu}$, et al. ${ }^{3}$.

The time-dependent formation of these larger dissolved org-I compounds could be due to smaller dissolved compounds binding together via weak chemical forces or the influence of microbial activity. The iodination of SOM in acidic conditions was shown to be predominantly an abiotic process, however, in less acidic conditions $(\mathrm{pH} \geq 5)$, microbial assisted iodination of SOM was 
doi: 10.1021/acs.est.9b02296

observed. ${ }^{3}$ Whilst microbial activity is generally not deemed essential for the transformation of $\mathrm{IO}_{3}{ }^{-}$into org-I (which seems to be primarily controlled by abiotic processes ${ }^{6}$ ), microbial laccases have been shown to enhance $\mathrm{I}^{-}$sorption in soils. ${ }^{53}$ Microbiological activities have previously been reported to incorporate $\mathrm{I}^{-}$with humic acids and soils with a relatively HMW and low mobility. ${ }^{33}$ Heumann, et al. ${ }^{60}$ identified that in the presence of microorganisms the production HMW org-I compounds significantly increased over an 8 week period; in contrast Figure 3 demonstrates that formation of relatively HMW compounds occurred over 20-40 hrs.

It has previously been suggested that the rapid rate of reaction of I with SOM could be beneficial, as humus may act as a natural barrier, accumulating any radioiodine released from nuclear waste repositories as immobile org-I compounds. ${ }^{18}$ Following a radioiodine contamination event limited soil-to-crop transfer would be beneficial for reducing the risk and duration of potentially harmful exposure. ${ }^{18,61,62}$ The short-term experiments presented in this paper show that a relatively small proportion of inorganic- ${ }^{129} \mathrm{I}$ is rapidly incorporated into LMW organic compounds $(<2.5 \mathrm{hr})$ which, over time, can be sorbed to the solid soil phase or bind together to form HWM organic compounds ( $\sim 30 \mathrm{hr})$.

Evaluating the short-term transport, speciation and fate of $\mathrm{I}$ in soil is critical to assess the environmental mobility and plant availability, as ${ }^{127} \mathrm{I}$ is an essential micronutrient for which dietary intake often depends on the transfer of I from soil-to-crops. ${ }^{63}$ Soil I concentrations are dependent on the deposition of volatized I compounds from seawater. ${ }^{11}$ Specific rainfall characteristics influence the concentration of I in rainfall and soil properties affect the volume of I retained by soils that would be accessible for plant uptake. ${ }^{5}$ Passive uptake is the predominant pathway for I absorption in plants, ${ }^{30}$ as such, plant uptake is highly dependent upon the concentration in the soil solution phase. By using ${ }^{129} \mathrm{I}$ as a proxy for ${ }^{127} \mathrm{I}$, it is possible to predict how much soluble I is 
doi: 10.1021/acs.est.9b02296

317 available for plant uptake following an addition event. We demonstrate that I only remains in the soil solution phase for a very limited period, before being sorbed on to inorganic soil phases or immobilized by SOM. Consequently, there is a severely limited window of opportunity for plants to absorb I from the soil solution immediately following rainfall or irrigation and limits the transfer of I to animal and human diets. However, this study did not investigate the impact of rewetting and remobilization of I bound to the solid soil phase, and this is should be the subject of further research. Considering that there are an estimated 1.9 billion people at risk of I deficiency worldwide, ${ }^{64}$ the findings in this paper may contribute to better understanding of the efficacy of phytofortification strategies.

\section{Supporting Information}

Additional information on analytical methods and supplementary results. 
doi: 10.1021/acs.est.9b02296

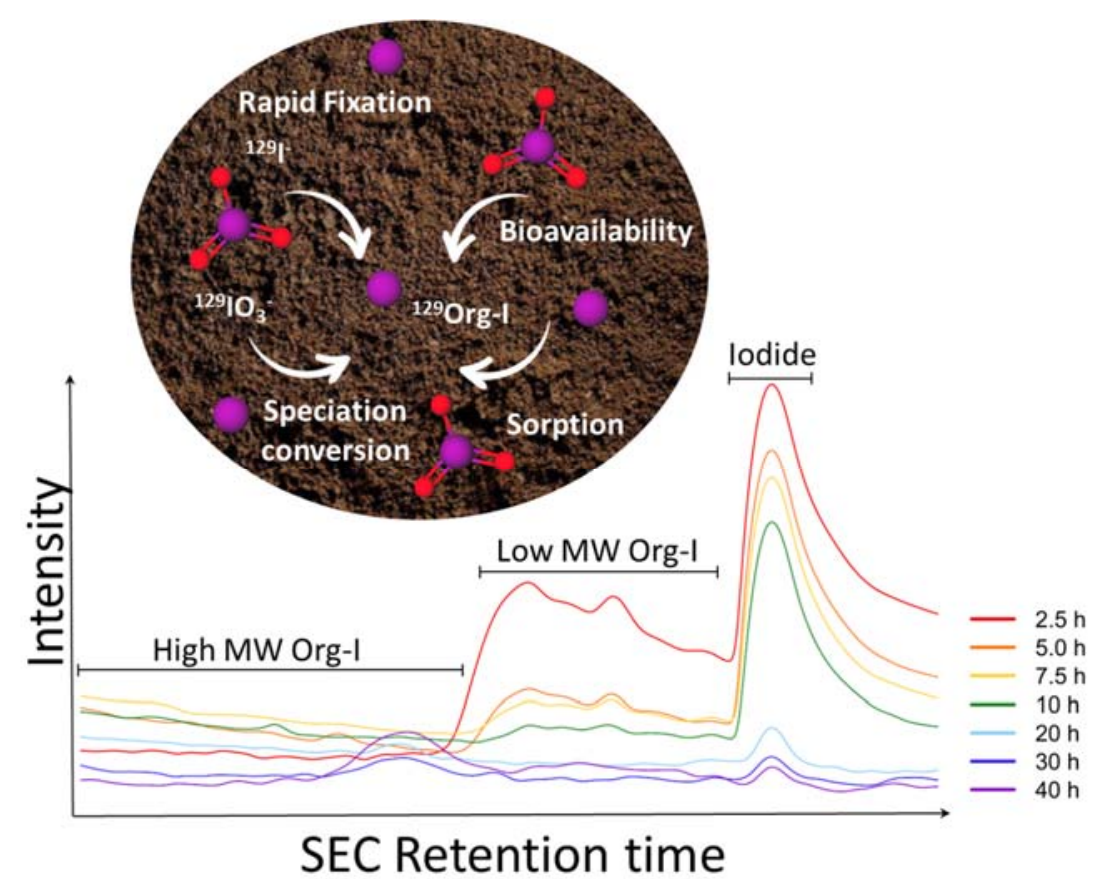

\section{AUTHOR INFORMATION}

Corresponding Author

*Corresponding author: Michael J. Watts; Email: mwatts@bgs.ac.uk; telephone number: 0115936

\section{Present Addresses}

$\dagger$ Inorganic Geochemistry, Centre for Environmental Geochemistry, British Geological Survey, Keyworth, Nottingham, NG12 5GG, UK.

\section{Author Contributions}

The manuscript was written through contributions from all authors. All authors have given approval to the final version of the manuscript. 
doi: 10.1021/acs.est.9b02296

\section{Conflict of Interest}

The authors declare no competing financial interest.

\section{ACKNOWLEDGMENT}

Funding for O. S. Humphrey was provided by The British Geological Survey-University of

Nottingham Centre for Environmental Geochemistry. BGS University Funding Initiative

(contract number: BUFI-S314). This work is published with the permission of the Executive

Director, British Geological Survey.

\section{REFERENCES}

1. WHO; UNICEF; ICCIDD., Assessment of Iodine Deficiency Disorders and monitoring their Elimination. World Health Organization Press: Geneva, Switzerland 2007.

2. Zimmermann, M. B.; Jooste, P. L.; Pandav, C. S., Iodine-deficiency disorders. The Lancet 2008, 372, (9645), 1251-1262.

3. Xu, C.; Miller, E. J.; Zhang, S.; Li, H.-P.; Ho, Y.-F.; Schwehr, K. A.; Kaplan, D. I.; Otosaka, S.; Roberts, K. A.; Brinkmeyer, R.; Yeager, C. M.; Santschi, P. H., Sequestration and Remobilization of Radioiodine (129I) by Soil Organic Matter and Possible Consequences of the Remedial Action at Savannah River Site. Environmental Science \& Technology 2011, 45, (23), 9975-9983.

4. Takeda, A.; Tsukada, H.; Takaku, Y.; Satta, N.; Baba, M.; Shibata, T.; Hasegawa, H.; Unno, Y.; Hisamatsu, S., Determination of Iodide, Iodate and Total Iodine in Natural Water Samples by HPLC with Amperometric and Spectrophotometric Detection, and Off-line UV Irradiation. Analytical Sciences 2016, 32, (8), 839-845.

5. Shetaya, W. H.; Young, S. D.; Watts, M. J.; Ander, E. L.; Bailey, E. H., Iodine dynamics in soils. Geochimica et Cosmochimica Acta 2012, 77, 457-473.

6. Yamaguchi, N.; Nakano, M.; Takamatsu, R.; Tanida, H., Inorganic iodine incorporation into soil organic matter: evidence from iodine K-edge X-ray absorption near-edge structure. Journal of Environmental Radioactivity 2010, 101, (6), 451-457.

7. Bowley, H. E.; Young, S. D.; Ander, E. L.; Crout, N. M. J.; Watts, M. J.; Bailey, E. H., Iodine binding to humic acid. Chemosphere 2016, 157, 208-214.

8. Yamada, H.; Kiriyama, T.; Onagawa, Y.; Hisamori, I.; Miyazaki, C.; Yonebayashi, K., Speciation of iodine in soils. Soil science and plant nutrition 1999, 45, (3), 563-568.

9. Shimamoto, Y. S.; Takahashi, Y.; Terada, Y., Formation of Organic Iodine Supplied as Iodide in a Soil-Water System in Chiba, Japan. Environmental Science \& Technology 2011, 45, (6), 2086-2092.

10. Whitehead, D. C., The sorption of iodide by soils as influenced by equilibrium conditions and soil properties. Journal of the Science of Food and Agriculture 1973, 24, (5), 547-556. 
11. Humphrey, O. S.; Young, S. D.; Bailey, E. H.; Crout, N. M. J.; Ander, E. L.; Watts, M. J., Iodine soil dynamics and methods of measurement: a review. Environmental Science: Processes \& Impacts 2018, 20, (2), 288-310.

12. Schwehr, K. A.; Santschi, P. H.; Kaplan, D. I.; Yeager, C. M.; Brinkmeyer, R., OrganoIodine Formation in Soils and Aquifer Sediments at Ambient Concentrations. Environmental Science \& Technology 2009, 43, (19), 7258-7264.

13. Kodama, S.; Takahashi, Y.; Okumura, K.; Uruga, T., Speciation of iodine in solid environmental samples by iodine K-edge XANES: Application to soils and ferromanganese oxides. Science of The Total Environment 2006, 363, (1-3), 275-284.

14. Shimamoto, Y. S.; Itai, T.; Takahashi, Y., Soil column experiments for iodate and iodide using K-edge XANES and HPLC-ICP-MS. Journal of Geochemical Exploration 2010, 107, (2), 117-123.

15. Gallard, H.; Allard, S. b.; Nicolau, R.; Von Gunten, U.; Croué, J. P., Formation of iodinated organic compounds by oxidation of iodide-containing waters with manganese dioxide. Environmental science \& technology 2009, 43, (18), 7003-7009.

16. Warner, J. A.; Casey, W. H.; Dahlgren, R. A., Interaction Kinetics of I2(aq) with Substituted Phenols and Humic Substances. Environmental Science \& Technology 2000, 34, (15), 3180-3185.

17. Kaplan, D. I., Influence of surface charge of an Fe-oxide and an organic matter dominated soil on iodide and pertechnetate sorption. Radiochim. Acta 2003, 91, 173-178.

18. Xu, C.; Zhang, S.; Ho, Y.-F.; Miller, E. J.; Roberts, K. A.; Li, H.-P.; Schwehr, K. A.; Otosaka, S.; Kaplan, D. I.; Brinkmeyer, R.; Yeager, C. M.; Santschi, P. H., Is soil natural organic matter a sink or source for mobile radioiodine (129I) at the Savannah River Site? Geochimica et Cosmochimica Acta 2011, 75, (19), 5716-5735.

19. Miró, M.; Jimoh, M.; Frenzel, W., A novel dynamic approach for automatic microsampling and continuous monitoring of metal ion release from soils exploiting a dedicated flow-through microdialyser. Analytical and Bioanalytical Chemistry 2005, 382, (2), 396-404.

20. Brackin, R.; Näsholm, T.; Robinson, N.; Guillou, S.; Vinall, K.; Lakshmanan, P.; Schmidt, S.; Inselsbacher, E., Nitrogen fluxes at the root-soil interface show a mismatch of nitrogen fertilizer supply and sugarcane root uptake capacity. Scientific Reports 2015, 5, 15727. 21. Buckley, S.; Brackin, R.; Näsholm, T.; Schmidt, S.; Jämtgård, S., Improving in situ recovery of soil nitrogen using the microdialysis technique. Soil Biology and Biochemistry 2017, 114, 93-103.

22. Demand, D.; Schack-Kirchner, H.; Lang, F., Assessment of diffusive phosphate supply in soils by microdialysis. Journal of Plant Nutrition and Soil Science 2017, (180), 220-230.

23. Humphrey, O. S.; Young, S. D.; Bailey, E. H.; Crout, N. M. J.; Ander, E. L.; Hamilton, E. M.; Watts, M. J., Investigating the use of microdialysis and SEC-UV-ICP-MS to assess iodine interactions in soil solution. Chemosphere 2019, 229, 41-50.

24. Grace, C.; Hart, M.; Brookes, P. C., Laboratory manual of the soil microbial biomass group. Rothamsted Research 2006, 65.

25. Watts, M.; Mitchell, C., A pilot study on iodine in soils of Greater Kabul and Nangarhar provinces of Afghanistan. Environmental Geochemistry and Health 2009, 31, (4), 503-509.

26. Mehra, O. P.; Jackson, M. L., Iron oxide removal from soils and clays by a dithionitecitrate system buffered with sodium bicarbonate. In Clays Clay Miner, Pergamon: 1960; pp 317327. 
doi: 10.1021/acs.est.9b02296

27. Rawlins, B. G.; Wragg, J.; Lark, R. M., Application of a novel method for soil aggregate stability measurement by laser granulometry with sonication. European Journal of Soil Science 2013, 64, (1), 92-103.

28. Yntema, L. F.; Fleming, T., Volumetric Oxidation of Iodide to Iodate by Sodium Chlorite. Industrial \& Engineering Chemistry Analytical Edition 1939, 11, (7), 375-377.

29. Clough, G. F., Microdialysis of large molecules. The AAPS Journal 2005, 7, (3), E686E692.

30. Humphrey, O. S.; Young, S. D.; Bailey, E. H.; Crout, N. M. J.; Ander, E. L.; Hamilton, E. M.; Watts, M. J., Iodine uptake, storage and translocation mechanisms in spinach (Spinacia oleracea L.). Environmental Geochemistry and Health 2019, 41, (5), 2145-2156.

31. Yamada, H.; Hisamori, I.; Yonebayashi, K., Identification of organically bound iodine in soil humic substances by size exclusion chromatography / inductively coupled plasma mass spectrometry (SEC / ICP-MS). Soil Science and Plant Nutrition 2002, 48, (3), 379-385.

32. Rädlinger, G.; Heumann, K. G., Determination of halogen species of humic substances using HPLC/ICP-MS coupling. Fresenius J Anal Chem 1997, 359, (4-5), 430-433.

33. Rädlinger, G.; Heumann, K. G., Transformation of Iodide in Natural and Wastewater Systems by Fixation on Humic Substances. Environmental Science \& Technology 2000, 34, (18), 3932-3936.

34. Takeda, A.; Tsukada, H.; Takaku, Y.; Hisamatsu, S. i., Fractionation of metal complexes with dissolved organic matter in a rhizosphere soil solution of a humus-rich Andosol using size exclusion chromatography with inductively coupled plasma-mass spectrometry. Soil Science and Plant Nutrition 2009, 55, (3), 349-357.

35. Shah, M.; Wuilloud, R. G.; Kannamkumarath, S. S.; Caruso, J. A., Iodine speciation studies in commercially available seaweed by coupling different chromatographic techniques with UV and ICP-MS detection. Journal of Analytical Atomic Spectrometry 2005, 20, (3), 176182.

36. Sheppard, M.; Thibault, D.; Smith, P.; Hawkins, J., Volatilization: a soil degassing coefficient for iodine. Journal of environmental radioactivity 1994, 25, (3), 189-203.

37. Schlegel, M. L.; Reiller, P.; Mercier-Bion, F.; Barré, N.; Moulin, V., Molecular environment of iodine in naturally iodinated humic substances: Insight from X-ray absorption spectroscopy. Geochimica et Cosmochimica Acta 2006, 70, (22), 5536-5551.

38. Steinberg, S. M.; Schmett, G. T.; Kimble, G.; Emerson, D. W.; Turner, M. F.; Rudin, M., Immobilization of fission iodine by reaction with insoluble natural organic matter. Journal of Radioanalytical and Nuclear Chemistry 2008, 277, (1), 175-183.

39. Francois, R., The influence of humic substances on the geochemistry of iodine in nearshore and hemipelagic marine sediments. Geochimica et Cosmochimica Acta 1987, 51, (9), 2417-2427.

40. Brummer, J. G.; Field, R. J., Kinetics and mechanism of the oxidation of ferrous ion by iodate ion in strong perchloric acid, aqueous media. Journal of Physical Chemistry 1979, 83, (18), 2328-2335.

41. Whitehead, D. C., The distribution and transformations of iodine in the environment. Environment International 1984, 10, (4), 321-339.

42. Mackowiak, C. L.; Grossl, P. R.; Cook, K. L., Iodine toxicity in a plant-solution system with and without humic acid. Plant and Soil 2005, 269, (1-2), 141-150.

43. Kaplan, D. I.; Serne, R. J.; Parker, K. E.; Kutnyakov, I. V., Iodide sorption to subsurface sediments and illitic minerals. Environmental Science \& Technology 2000, 34, (3), 399-405. 
44. Yoshida, S.; Muramatsu, Y.; Uchida, S., Studies on the sorption of I- (iodide) and IO3 (iodate) onto Andosols. Water, Air, and Soil Pollution 1992, 63, (3), 321-329.

45. Whitehead, D. C., The influence of organic matter, chalk, and sesquioxides on the solubility of iodide, elemental iodine, and iodate incubated with soil. Journal of Soil Science 1974, 25, (4), 461-470.

46. Yoshida, S.; Muramatsu, Y.; Katou, S.; Sekimoto, H., Determination of the chemical forms of iodine with IC-ICP-MS and its application to environmental samples. Journal of Radioanalytical and Nuclear Chemistry 2007, 273, (1), 211-214.

47. Yamada, H.; Kiriyama, T.; Yonebayashi, K., Determination of Total Iodine in Soils by Inductively Coupled Plasma Mass Spectrometry. Soil Science and Plant Nutrition 1996, 42, (4), 859-866.

48. Muramatsu, Y.; Uchida, S.; Sumiya, M.; Ohmomo, Y.; Obata, H., Tracer experiments on transfer of radio-iodine in the soil-rice plant system. Water, Air, and Soil Pollution 1989, 45, (1-2), 157-171.

49. Zhang, S.; Du, J.; Xu, C.; Schwehr, K.; Ho, Y.-F.; Li, H.-P.; Roberts, K.; Kaplan, D.; Brinkmeyer, R.; Yeager, C., Concentration-dependent mobility, retardation, and speciation of iodine in surface sediment from the Savannah River Site. Environmental science \& technology 2011, 45, (13), 5543-5549.

50. Muramatsu, Y.; Uchida, S.; Sriyotha, P.; Sriyotha, K., Some considerations on the sorption and desorption phenomena of iodide and iodate on soil. Water, Air, and Soil Pollution 1990, 49, (1), 125-138.

51. Yamaguchi, N.; Nakano, M.; Tanida, H.; Fujiwara, H.; Kihou, N., Redox reaction of iodine in paddy soil investigated by field observation and the I K-Edge XANES fingerprinting method. Journal of Environmental Radioactivity 2006, 86, (2), 212-226.

52. Amachi, S., Microbial Contribution to Global Iodine Cycling: Volatilization, Accumulation, Reduction, Oxidation, and Sorption of Iodine. Microbes and Environments 2008, 23, (4), 269-276.

53. Seki, M.; Oikawa, J.-i.; Taguchi, T.; Ohnuki, T.; Muramatsu, Y.; Sakamoto, K.; Amachi, S., Laccase-Catalyzed Oxidation of Iodide and Formation of Organically Bound Iodine in Soils. Environmental Science \& Technology 2012, 47, (1), 390-397.

54. Amachi, S.; Kasahara, M.; Hanada, S.; Kamagata, Y.; Shinoyama, H.; Fujii, T.; Muramatsu, Y., Microbial Participation in Iodine Volatilization from Soils. Environmental Science \& Technology 2003, 37, (17), 3885-3890.

55. Fox, P. M.; Davis, J. A.; Luther III, G. W., The kinetics of iodide oxidation by the manganese oxide mineral birnessite. Geochimica et Cosmochimica Acta 2009, 73, (10), 28502861.

56. Allard, S.; von Gunten, U.; Sahli, E.; Nicolau, R.; Gallard, H., Oxidation of iodide and iodine on birnessite $(\delta-\mathrm{MnO} 2)$ in the $\mathrm{pH}$ range 4-8. Water Research 2009, 43, (14), 3417-3426. 57. Sheppard, M. I.; Thibault, D. H., Chemical behaviour of iodine in organic and mineral soils. Applied Geochemistry 1992, 7, (3), 265-272.

58. Tikhomirov, F. A.; Kasparov, S. V.; Prister, B. S.; Sal'nikov, V. n., Role of organic matter in iodine fixation in soils. Soviet Soil Science 1980, 12, (1), 64-72.

59. Hu, Q. H.; Moran, J. E.; Gan, J. Y., Sorption, degradation, and transport of methyl iodide and other iodine species in geologic media. Applied Geochemistry 2012, 27, (3), 774-781. 
60. Heumann, K. G.; Rädlinger, G.; Erbes, M.; Heiber, I.; Obst, U.; Filip, Z.; Claus, H., Ageing of Dissolved Halogenated Humic Substances and the Microbiological Influence on this Process. Acta hydrochimica et hydrobiologica 2000, 28, (4), 193-201. 61. Xu, C.; Zhong, J.; Hatcher, P. G.; Zhang, S.; Li, H.-P.; Ho, Y.-F.; Schwehr, K. A.; Kaplan, D. I.; Roberts, K. A.; Brinkmeyer, R., Molecular environment of stable iodine and radioiodine (129I) in natural organic matter: Evidence inferred from NMR and binding experiments at environmentally relevant concentrations. Geochimica et Cosmochimica Acta 2012, 97, 166-182. Organoiodine formation during humification in peatlands. Environmental Chemistry Letters 2003, 1, (4), 219-223. 63. Watts, M.; Joy, E.; Young, S.; Broadley, M.; Chilimba, A.; Gibson, R.; Siyame, E.; Kalimbira, A.; Chilima, B.; Ander, E., Iodine source apportionment in the Malawian diet. Scientific reports 2015, 5, (15251). deficiency in pregnant women in Europe. The Lancet Diabetes \& Endocrinology 2015, 3, (9), 672-674. 